\title{
Upcycling of manure with insects: current and future prospects
}

\author{
J.A. Cammack ${ }^{1 *}$, C.D. Miranda ${ }^{1}$, H.R. Jordan ${ }^{2}$ and J.K. Tomberlin ${ }^{3}$ \\ ${ }^{1}$ EVO Conversion Systems, LLC, 5552 Raymond Stotzer Pkwy, College Station, TX 77845, USA ${ }^{2}$ Department of Biological \\ Sciences, Mississippi State University, P.O. Box GY, Starkville, MS 39762, USA; ${ }^{3}$ Department of Entomology, Texas AEM \\ University, 410 Minnie Belle Heep, College Station, TX 77843, USA; jacammack@evoconsys.com
}

Received: 30 July 2020 / Accepted: 15 October 2020

(c) 2021 Wageningen Academic Publishers

OPEN ACCESS CC) REVIEW ARTICLE

\begin{abstract}
An unavoidable by-product of any animal production system, be it vertebrate- or invertebrate-based, is the manure generated by the animals themselves. In this review, we focus on the role that insects, particularly the black soldier fly Hermetia illucens (L.) (Diptera: Stratiomyidae), could play in managing the mass amount of manure produced through animal agriculture, and the subsequent commodities that could be generated by such a system. Although the focus of this review is on the black soldier fly, we postulate that other species, including the lesser mealworm Alphitobius diaperinus (Panzer) (Coleoptera: Tenebrionidae) and the house fly Musca domestica L. (Diptera: Muscidae) are also well poised to help with the challenge of managing animal manure, while generating products of value.
\end{abstract}

Keywords: manure management, sustainable agriculture, lesser mealworm, house fly, black soldier fly, circular economy

\section{Introduction}

The insects as feed industry is positioned to alleviate many of the environmental burdens associated with livestock production, such as diverting plant protein to human consumption, reducing pressure on international fisheries for fish oil and fish meal, land use, and water required to generate protein. Although using insect products as components of livestock feed could allow for more sustainable (i.e. efficient and environmentallyconscious) meat production, one environmental issue that remains is manure management and its associated negative environmental impacts (e.g. runoff, eutrophication, groundwater contamination, greenhouse gas and volatile organic compound emissions, and proliferation of pest species and pathogens) (Adhikari et al., 2005; Beskin et al., 2018; Chang and Janzen, 1996; Cossé and Baker, 1996; FAO, 2006; Kyakuwaire et al., 2019).

Over the past $25+$ years, structural changes in animal production across the globe (i.e. reduction in total farm numbers and an increase in the number of animals per farm) have resulted in large quantities of manure in smaller areas, that must be properly managed. For example, from 1970 to 2006, the number of USA dairy farms decreased by $88 \%$, while average herd size increased six-fold, and milk production twelve-fold (MacDonald et al., 2007). Traditionally, a majority (70\% in 1994) of swine produced in the USA was from small operations $(<5,000$ head/ operation). By 2014, large operations $(5,000+$ head/ operation) accounted for $90 \%$ of annual production (United States Department of Agriculture, 2015). A similar trend has occurred in the broiler industry. From 1995 to 2010, the number of broiler firms decreased from 55 to 41 (Davis et al., 2013), while chicken meat production increased by $47 \%$ (National Chicken Council, 2019b). By 2019, the number of USA broiler firms dropped to 30 (National Chicken Council, 2019a), but chicken meat production increased by almost 19\% (National Chicken Council, 2019b). These trends are similar across the globe: in the European Union (EU), an estimated $90 \%$ of broilers were produced by large firms in 2018, with production increasing approximately $25 \%$ during the previous decade (Augére-Granier, 2019). From 1996-2006 in China, the number of poultry farms decreased by $67 \%$, while production increased by over $75 \%$ (FAO, 2008).

The evolution of these industries to larger facilities has amplified concerns regarding waste management, as the volume of manure produced outweighs the amount that 
may be utilised as fertiliser on nearby land. While manure is typically considered a valuable resource, like anything else, too much can be a major issue, and current methods of manure management (e.g. lagoons, composting, spreading, etc.) are inefficient, environmentally challenging, and not fully sustainable (Adhikari et al., 2005; Chang and Janzen, 1996; Edmonds et al., 2003; Grossman, 2014; Kyakuwaire et al., 2019; Welch and O'Hagan, 2010). Novel methods to manage manure that decrease the environmental impact and increase the sustainability of animal production are desperately needed; insects are likely ideal candidates for tackling such a global challenge.

\section{Insects that consume manure}

Although thousands of arthropods feed on animal manures, these relationships have been investigated mainly in natural habitats (Miller, 1954; Mohr, 1943; Nichols et al., 2017) with few species studied for manure management. Dung beetles (Coleoptera: Scarabaeidae) are widely studied for their impacts on manure recycling as related to pasture health (Bertone et al., 2006; Nichols et al., 2008), whereas most fly (Diptera) species associated with manure are typically regarded as pests, and research efforts are typically focused on their control (Axtell, 1986; Barth, 1986; Hall and Foehse, 1980; Sheppard, 1983). While the following three species discussed for manure management are by no means exhaustive, the knowledge-base of these species has them positioned as the most promising fits for this monumental task.

\section{Alphitobius diaperinus}

The lesser mealworm, Alphitobius diaperinus (Panzer) (Coleoptera: Tenebrionidae) is a small, dark beetle, with global distribution. Eggs are deposited in larval resources such as grains, poultry litter, and manure (Rumbos et al., 2019); resulting larvae complete development in 40 to $60 \mathrm{~d}$, while pupae require 7-12 d to develop to the adult stage (Axtell and Arends, 1990). When one considers the insect species frequently recommended for recycling animal manure, or used as protein, the lesser mealworm is not typically highlighted. Worldwide, this species is considered a primary pest of poultry production. Its presence signifies the potential for vectored pathogens (Crippen et al., 2009, 2012), reduced feed conversion by the birds, and damage to poultry houses (Lyons et al., 2017; Tomberlin et al., 2008). Thus, being labelled a pest is not a surprise, especially from the perspective of the poultry producer (Axtell and Arends, 1990).

However, the lesser mealworm might have more to offer than is appreciated (Rumbos et al., 2019). This species is commonly associated with manure, can develop massive populations in poultry facilities, and has a similar nutritional value to yellow mealworm (Tenebrio molitor (L.)), which is currently mass produced worldwide for food and feed (Rumbos et al., 2019). If facilities were designed to manage the population, lesser mealworms could possess the same potential as the black soldier fly Hermetia illucens (L.) (Diptera: Stratiomyidae) for recycling manure, while producing protein and associated compost.

Recall, the black soldier fly was considered a pest (Axtell and Edwards, 1970) long before it was recognised as the 'crown jewel' of the insects as feed industry (Tomberlin and Van Huis, 2020). Issues with this species ranged from destruction of poultry houses and inhibition of manure management, to causing myiasis (Tomberlin and Van Huis, 2020). While these are all accurate in terms of problems the black soldier fly can cause when present, harnessing its abilities eliminated these issues. Could the lesser mealworm be on the same path created by the industrialisation of the black soldier fly? Answering that question is challenging given its current pest status and lack of effort investigating its use to recycle waste and produce protein (Rumbos et al., 2019). However, the stage has been set for the industrial development of this species, as the European Union has taken the first step by approving its use as a feed (Leni et al., 2020). And, several studies have examined the nutritional value of this insect as a potential food and feed (Azzollini et al., 2019; Roncolini et al., 2020).

\section{Musca domestica}

Another insect known to feed on manure is the house fly, Musca domestica L. (Diptera: Muscidae). Owning up to its namesake, the house fly is commonly found in or around homes and is the most widely distributed insect, colonising every location where humans and domestic animals occur (Keiding, 1986). As such, its biology has been well described in an effort toward control. House flies fed milking calf, swine, or poultry manure can develop to pupae in as little as $6 \mathrm{~d}$ (Larrain and Salas, 2008), but manure type influences their performance and fitness (Khan et al., 2012; Larrain and Salas, 2008). Still, the house fly can consume manure from a variety of animals, including those produced from concentrated animal facilities (e.g. swine, dairy, and poultry) (Miranda et al., 2020a), which makes them a suitable candidate for manure management.

House flies can degrade large volumes of manure in a short amount of time. Compared to the lengthy time necessary for traditional composting, house fly larvae, depending on the density, have been demonstrated to digest over $100 \mathrm{~kg}$ of swine manure in one week (Zhang et al., 2012) and over 400 kg of swine manure in two weeks (Čičková et al., 2012). As larvae feed on manure, reductions in odours (Wang et al., 2013) and moisture (Miller et al., 1974; Wang et al., 2013) occur. These reductions can be attributed to changes in 
the microbial community, but the presence of house flies is also beneficial as they mechanically aerate the substrate, allowing the environment to remain aerobic for increased loss of gases and water (Beard and Sands, 1973). House flies also reduce antibiotic resistant genes in swine manure and in doing so, provide a biofertiliser that is less of a threat to the environment than untreated manure (Wang et al., 2015 , 2017). Additionally, the presence of house fly larvae can reduce swine manure mass (wet weight) by up to $70 \%$ (Wang et al., 2013), dry matter by 31-35\%. (Miranda et al., 2020a; Wang et al., 2013) and nitrogen and phosphorous by up to $78 \%$ and up to $30 \%$, respectively (Wang et al., 2013). The extent of total mass reductions (wet weight) for dairy and poultry manure by house flies on a full scale is not known as it is for swine manure, but house flies can reduce dry matter in dairy and poultry manure on a small scale by up to approximately 20 and $40 \%$, respectively (Miranda et al., 2020a).

House flies reduce nitrogen and phosphorous in dairy and poultry manure as well. For example, Hussein et al. (2017) determined house flies reduce nitrogen in dairy manure by $25 \%$ and phosphorous by $6 \%$ on a dry matter basis. In poultry manure, house flies reduced nitrogen from 7.5 to $2.6 \%$ and phosphorous from 3.4 to $1.9 \%$ on a dry matter basis (Teotia and Miller, 1974). At the same rate, the biomass generated from house flies fed manure is valuable as lipids extracted from larvae can be processed for biofuel (Zi-zhe et al., 2017).

Part of the challenge in using the house fly for waste management is that it is considered a pest, and like the lesser mealworm, is a vector of numerous pathogens (Keiding, 1986). There are multiple ways in which house flies harbour and disseminate pathogens. Since larvae partially rely on bacteria for development (Zurek et al., 2000), all life stages are associated with microbe-rich habitats. As larvae develop, some harmful bacteria may remain within the gut and can be carried through subsequent life-stages (Zurek and Nayduch, 2016). As an adult, they must feed to mature reproductively (Morrison and Davies, 1964) and so pathogens may be spread via regurgitation and excretion. Sasaki et al. (2000) showed Escherichia coli O157: $\mathrm{H} 7$ remained in the adult house fly crop for $4 \mathrm{~d}$ and was excreted for $3 \mathrm{~d}$ after feeding on contaminated food (Sasaki et al., 2000). Pathogens can also be disseminated by adults through mechanical contact via their tarsi (Wasala et al., 2013). Adult house flies are opportunistic and will move indiscriminately among locations in search of food or a place to oviposit. Yet, despite their behaviour and pest status, house flies offer a promising solution to waste management because of their ability to digest manure in a short amount of time.

\section{Hermetia illucens}

Compared to the previous insects discussed, the black soldier fly is currently the best insect candidate for manure management. Found in temperate and tropical regions throughout the world, the black soldier fly is now viewed as a non-pest species and is highly regarded due to the wide range of wastes it can digest (Alyokhin et al., 2019; Lalander et al., 2019; Nguyen et al., 2013). The life cycle of the black soldier fly takes approximately 40-43 d when fed an artificial diet, with the larval stage lasting 22-24 d (Cammack and Tomberlin, 2017; Tomberlin et al., 2002), which is nearly twice as long as the entire house fly life cycle. However, black soldier fly larvae are larger, capable of consuming more resource (Čičková et al., 2015), and possess a more diverse array of digestive enzymes when compared to house fly larvae (Kim et al., 2011b).

Research regarding black soldier fly larvae fed manure has largely focused on dairy, swine, or poultry manures (Diener et al., 2009; Miranda et al., 2019; Oonincx et al., 2015a; Zhou et al., 2013). All three manure types are suitable for their development; however, poultry manure appears to be optimal (Miranda et al., 2019; Zhou et al., 2013), likely because it has higher nutrient concentrations than the other manure types (Chen et al., 2003). Blending waste streams can increase the digestion and subsequent larval yield. This is particularly effective when feeding lower quality manure types, such as dairy manure. For example, feeding black soldier fly larvae a mixture of dairy and poultry manure (40 and 60\%, respectively) decreased development time by $2 \mathrm{~d}$, increased survivorship by $6 \%$, and increased larval weight by $\sim 75 \%$ when compared to larvae fed dairy manure alone (ur Rehman et al., 2017a). Similarly, other wastes (e.g. kitchen wastes, poultry slaughterhouse waste, fish offal, and human excrement) can be mixed with cow manure to improve black soldier fly survivorship, weight gain, and dry matter reduction (Gold et al., 2020; St-Hilaire et al., 2007). Black soldier fly digestion of manure also results in reduced production of odorous volatile organic compounds (Beskin et al., 2018), further contributing to their positive impact on the manure management system.

Currently, there is little information available on large-scale digestion of manure by black soldier fly larvae. Sheppard et al. (1994) developed a system where the innate behaviour of the black soldier fly larvae and prepupae could be harnessed to collect larvae produced from poultry layer manure that accumulated beneath the birds, and Newton et al. (2005) modified this system to manage manure generated from swine production (Newton et al., 2005; Sheppard et al., 1994). Industrialisation of the black soldier fly on different wastes certainly exists across the globe, but most research available on this species is studied on a small/ laboratory scale (hundreds of larvae fed grams of substrate). To our 
knowledge, there is only one study that has examined the development of black soldier fly larvae fed manure on a large scale $(10,000$ larvae fed $7 \mathrm{~kg}$ of swine, dairy, or poultry manure) (Miranda et al., 2020b). Despite the lack of information available on large-scale production of black soldier fly larvae fed manure, there is great potential for this species to serve as a waste management agent. Given their voracious appetite for all things decomposing, biomass accumulation, literature availability, and the current global focus of mass production, the remainder of this manuscript will focus on using the black soldier fly for manure management.

\section{Microbiology, black soldier fly, and manure}

The increasing human population has led to more intensive livestock farming, and with this comes concern about pathogens, antibiotics, and other pharmaceutical residues in animal manure shed into the environment with potential for increased accumulation of antibiotic resistant bacteria or human allergies from environmental exposure. Several pathogens comprising bacteria, viruses, and protozoan species, naturally occur in animal manure and under certain circumstances may pose a risk to human health. However, owing to differences in microbial characteristics between and within these groups of organisms, pathogen survival in the environment or manure depends on the characteristics of the particular organism, the source, and chemical composition of manure (e.g. ammonium content), $\mathrm{pH}$, dry matter, temperature, oxygen, microbial competition, and moisture of these materials (Haruta and Kanno, 2015; Manyi-Loh et al., 2016; Sheng et al., 2019). Bacterial pathogens that are most often associated with manure with regard to human health include Salmonella spp., E. coli O157:H7, Campylobacter jejuni, Listeria monocytogenes, Yersinia enterocolitica and Clostridium perfringens, some of which may be widely distributed in the environment and include over 2000 species and strains (Manyi-Loh et al., 2016; Sobsey et al., 2006). These bacterial pathogens may persist for long periods in animal manures under typical farm conditions. This may be extended when the temperatures are low, moisture remains optimal, and aeration is not used. For instance, E. coli O157:H7 survived for 4-6 months in animal manures and slurries kept at 1-9 ${ }^{\circ} \mathrm{C}, 49$ times longer than if kept at $40-60{ }^{\circ} \mathrm{C}$ (Kudva et al., 1998). Salmonella enterica serovar Typhimurium was also found to survive best at $5{ }^{\circ} \mathrm{C}$ for up to $40 \mathrm{~d}$, compared to 15 and $25^{\circ} \mathrm{C}$ (Garcia et al., 2010). Other studies have shown that aeration of solid manure decreased survival times for E. coli O157:H7 and Salmonella by as much as $88 \%$. The persistence of $L$. monocytogenes for several weeks in manure-amended soil, suggests it could be transmitted through soil, especially during the cold months (Jiang et al., 2004). Survival of protozoa in animal manures may also be related to temperature, but the trends are not as prominent as those reported for bacterial pathogens (Olson, 2020; Olsen et al., 1999).

Composting manure significantly reduces the risk of exposure to these pathogens, as the high temperatures $\left(\geq 54{ }^{\circ} \mathrm{C}\right)$ achieved during the process kills many pathogens and parasites. However, because of the pathogen diversity in manure, composting may not kill all pathogens, particularly those capable of forming spores or surviving in biofilms (Manyi-Loh et al., 2016; Stanford et al., 2015; Usui et al., 2017). Hence, multiple manure management practices should be used.

Insects, such as the lesser mealworm, house fly, or black soldier fly, may suppress many of these pathogens given their coprophagous nature. The larvae aerate the manure and also promote the growth of beneficial saprophytic microbes (Sarpong et al., 2019). And, as previously mentioned, their larvae may reduce or eliminate bacteria through direct ingestion and digestion or through the generation of antimicrobial compounds.

\section{Lab studies show black soldier fly larvae reduce pathogens in manure}

One of the first studies determining the ability of black soldier larvae to reduce manure-associated pathogens was in 2004, when Erickson et al. inoculated gfp-labelled E. coli O157:H7 and gfp-Salmonella enterica serovar Enteritidis into dairy, swine, and poultry manure (Erickson et al., 2004). They determined black soldier fly larvae significantly accelerated $E$. coli inactivation in poultry manure, while showing no effect in dairy manure. On the other hand, $E$. coli growth accelerated in swine manure. Storage conditions and $\mathrm{pH}$ likely impacted pathogen populations and black soldier fly antibacterial activity within the differing manure substrates. Larval feeding also reduced Salmonella in poultry manure, but the pathogen accumulated in the larvae. From these data, they speculated larval waste accumulation and increased moisture in older manure likely led to reduced larval feeding, and a decrease in Salmonella Enteritidis inactivation (Erickson et al., 2004).

A study investigating the reduction of $E$. coli in manure was conducted in 2008 (Liu et al., 2008), when gfp-E. coli was inoculated into 50-125 g sterile dairy manure with or without black soldier fly larvae for $72 \mathrm{~h}$ at $23,27,31$ or $35^{\circ} \mathrm{C}$. Black soldier fly larvae significantly reduced $E$. coli counts in all manure weight treatments, but the capacity to reduce $E$. coli populations was temperature dependent, with greatest suppression occurring at $27^{\circ} \mathrm{C}$. Additionally, pathogen accumulation within the larvae was not determined.

Lalander et al. (2015) measured the effects of black soldier fly larvae feeding on the concentration of Salmonella spp., 
Enterococcus spp., the $\Phi \mathrm{X} 174$ bacteriophage, and the parasite Ascaris suum in human faecal waste, and whether these accumulated in, or on, the prepupae (Lalander et al., 2015). Salmonella spp. count in the waste was reduced by $6 \log _{10}$ in eight days, compared with a $<2 \log _{10}$ reduction in the control. However, they found no significant reduction of Enterococcus spp., bacteriophage ФX174 or A. suum ova associated with larval feeding. In contrast to Erickson et al. (2004), the Salmonella spp. concentration was $10^{5} \mathrm{cfu} /$ $\mathrm{ml}$ at the start of the experiment but decreased to below the detection limit in both the waste and prepupae as the experiment progressed, even though freshly inoculated material was continuously added. Concentrations of Enterococcus and bacteriophage $\Phi \mathrm{X} 174$ remained between $10^{5}$ and $10^{6} \mathrm{cfu} / \mathrm{ml}$ in larval guts. Also, there was an overall lower concentration of organisms found inside the gut of the prepupae compared with the gut of the larvae, suggesting that the prepupae empty their gut prior to dispersal (Lalander et al., 2015). These studies of pathogen inoculation have led to data supporting the utilisation of black soldier fly larvae for waste management. However, more studies are needed to determine industrial scale applications, as well as the accumulation of these and other manure-associated pathogens throughout black soldier fly life stages, and whether transmission occurs between generations. Research into the means to achieve absolute pathogen removal from the system when using insects to digest waste should also be considered.

For instance, it is well known that insect endosymbionts can confer ecologically relevant traits and contribute to the fitness of their host through outcompeting pathogens (Eleftherianos et al., 2013; Kaltenpoth, 2009; Kaltenpoth et al., 2005; Paniagua Voirol et al., 2018). Symbiotic bacteria often facilitate degradation of complex macromolecules for utilisation and increasing nutrient quality for the insect. Yu et al. (2011) measured black soldier fly larval growth and development when fed poultry manure inoculated with four Bacillus subtilis strains isolated from black soldier fly larval guts or from feed. They found that bacterial amendment increased larval growth while shortening the development time. Mazza et al. (2020) explored the effect of companion bacteria when poultry manure was converted to insect biomass. They isolated nine bacterial species from black soldier fly eggs and larval gut and inoculated them into poultry manure along with black soldier fly larvae. Results indicated that black soldier fly larvae reared in manure with Kocuria marina, Lysinibacillus boronitolerans, Proteus mirabilis and B. subtilis, alone or in combination, had higher weight gain and protein content and increased manure reduction rates compared to the control (Mazza et al., 2020). Both of these studies showed that bacterial amendment into the manure was beneficial with respect to black soldier fly larval development and manure reduction. This nutrient provisioning with probiotics, along with natural mechanisms of pathogen reduction within the black soldier fly can be exploited and represent a promising strategy for manure reduction, with potential for pathogen control.

\section{Feeding black soldier flies to livestock reduces gut pathogens}

Another avenue of research has been the investigation of insects used as feed to reduce pathogens in the digestive tract of traditional livestock through modulation of gut microbiota and their metabolites. For instance, Park et al. (2017) showed that laying hens fed black soldier fly larval meal had higher Lactobacillus counts, but coliforms, total aerobic bacteria, and E. coli were lower than in those not provided the insect-based diet. Another study by Kim et al. (2020) found that laying hens fed diets containing black soldier fly oil lowered C. perfringens counts in the ileum, but not cecum samples, by $13.7 \%$ at $30 \mathrm{~d}$, indicating moderate, although nonsignificant, antimicrobial activity of black soldier fly larvae oil in broilers.

Borrelli et al. (2017) used 16s rRNA gene sequencing to investigate the effect of black soldier fly larval meal on gastrointestinal microbiomes and bacterial metabolite production in laying hens. Results showed strong differences between caecal microbiota of soybean and black soldier fly meal fed groups, both in type and relative abundance of microbial species. They found microbial DNA signatures with potential to degrade the insect meal that correlated with high levels of gut-associated short chain fatty acid (SCFA) production. The authors suggested the increase in SCFA concentrations may result from modulation in the microbial population induced by the insect-based diet and may be associated with SCFAs derived by microbial degradation of the insect meal. Because SCFAs regulate bacterial pathogenesis (Sun and O'Riordan, 2013, and references therein), they speculated the possible beneficial effects of a black soldier fly larval meal diet (Borrelli et al., 2017). Though further studies are necessary to determine the impact of this feeding strategy on human and animal physiology and long-term health, these studies suggest that feeding animals with black soldier fly larvae meal or oil modulate gut microbes, and merits further investigation into the potential for pathogen reduction in resulting manure.

\section{Larval black soldier fly production of antimicrobial peptides}

Antimicrobial peptides (AMPs) are short and generally positively charged peptides with the ability to kill microbial pathogens directly, or indirectly by modulating host defences. These peptides are found in a wide variety of life forms from microorganisms to humans and are also part of 
the innate immunity of insects (Sierra et al., 2017; Wu et al., 2018). These insect peptides exhibit antimicrobial activity through disruption of pathogen membranes and have been associated with lower levels of antimicrobial resistance (Wu et al., 2018). As a result, insects have been surveyed for novel AMPs, and several studies have shown that black soldier fly larvae could be a rich source. Elhag et al. (2017) identified seven gene fragments of three types of AMPs in black soldier fly larvae. One gene, named stomoxynZH1, was shown to have diverse inhibitory activity on Staphylococcus aureus, E. coli, fungus Rhizoctonia solani Khün (rice)-10, and fungus Sclerotinia sclerotiorum (Lib.) (Elhag et al., 2017).

In another study, Vogel et al. (2018) fed black soldier fly larvae diets supplemented with four inoculated bacterial mixtures and variable organic plant waste and measured the immune related transcriptome. The authors identified 53 genes encoding putative AMPs, including 26 putative defensins, from the black soldier fly transcriptome. Larval protein and lipid extracts also showed a broad range of antibacterial activity. And, Alvarez et al. (2019) isolated peptides from E. coli challenged and control black soldier fly larvae, and tested their anti-Helicobacter pylori activity. The authors found over 90 peptides in their analysis, four of which they determined to have pronounced anti-H. pylori activity. But only larvae injected with $E$. coli were found to have anti-H. pylori antimicrobial peptides, suggesting that these peptides were produced in response to $E$. coli challenge (Alvarez et al., 2019).

These studies showed that AMP activity was dependent on diet and associated with bacterial loads within the diet. Additionally, immune challenge was induced with a needle prick, with AMP activity measured between 24-72 h post infection (Alvarez et al., 2019; Elhag et al., 2017; Vogel et al., 2018). It would thus be interesting to measure AMP activity of black soldier fly actively feeding on animal manures versus a control. This would allow measurement of black soldier fly AMPs under constant exposure to a wide array of microbial pathogens.

\section{Black soldier fly larvae degrade pharmaceuticals and reduce antibiotic resistance genes in manure}

Antibiotic residues are frequently detected in livestock wastes, where mechanisms of dissemination into the environment may be through the direct spreading of manure onto fields, processed in lagoon slurry, or spreading solids for livestock bedding (Wallace et al., 2018). Often, antibiotic residues have been detected at levels much higher (as much as 28,000 times) than in background soil or water (Chee-Sanford et al., 2009; Sim et al., 2011). And, though the abundance of antibiotic residues in livestock waste varies among livestock farm types, and regional regulations, the most frequently detected antibiotic residues include those from the fluoroquinolone, sulphonamide, and tetracycline drug classes, though other classes such as trimethroprim and macrolides have also been detected (Chee-Sanford et al., 2009; Prosser and Sibley, 2015; Wallace et al., 2018; Yuan et al., 2019). While further research needs to be conducted to determine the full impact on human, animal, and ecosystem health, there is general agreement within public and private entities that mitigation strategies should be implemented to prolong the effectiveness of currently used antibiotics while lessening the dissemination of antibiotic resistant bacteria and genes (Carbajal et al., 2017; CDC, 2015; EU, 2016; World Health Organization, 2015)

A recent and exciting finding is the black soldier fly larvaemediated degradation of pharmaceuticals. A study showed black soldier fly larvae degraded three pharmaceuticals (e.g. carbamazepine, roxithromycin and trimethoprim) and two pesticides (e.g. azoxystrobin and propiconazole) in a composting system, with no bioaccumulation within the larvae detected (Lalander et al., 2016). Recently, Cai et al. (2018b) showed that black soldier fly larvae can degrade tetracycline. Further, the authors found that intestinal bacterial and fungal communities were significantly modified. They also detected an increase in tet gene copy number (tetracycline resistance gene) in the gut microbial community, suggesting gut microbes increased tetracycline tolerance by black soldier fly and facilitated tetracycline biodegradation. Their analyses suggested synergistic mechanisms of tetracycline degradation between intestinal microbes and black soldier fly larvae including hydrolysis, oxygenation, deamination, demethylation, ring-cleavage and modification, where degradation products could serve as nutritional resources (Cai et al., 2018b). As a follow-up to this work, Cai et al. (2018a) investigated the impact of larval sterility on the bioconversion of poultry manure and the persistence of associated antibiotic resistance genes (ARGs). The authors used qPCR targeting 11 tetracycline resistance genes and 2 integrase genes and found that nonsterile black soldier fly larvae reduced ARGs by $95 \%$, versus 88.7 and $48.4 \%$ in sterile larvae and controls, respectively. This significant difference between treatments suggested a synergistic effect between intestinal microbes and black soldier fly in ARG reduction mechanisms. They also showed a shift in the microbial community, with decreases in human pathogens within the waste by $70-92 \%$. Furthermore, they found that environmental factors that were altered by larval activity, such as $\mathrm{pH}$ and nitrogen content, influenced bacterial community composition, and thus the persistence of ARGs (Cai et al., 2018a).

Overall, these results are promising for developing strategies for accelerating the degradation of antibiotics by adjusting the intestinal microbiota of black soldier fly larvae. But, though encouraging, these studies only targeted a few ARGs for detection, limiting elucidation of the impact of black soldier fly larvae and associated microbes on a broad 
range of ARGs and mechanisms. And recently, Gao et al. (2019) measured life histories of 4-day old black soldier fly larvae fed with diet supplemented with sulphonamides (e.g. sulphamonomethoxine, sulfamethoxazole, sulfamethazine, and sulfadiazine) in $0.1,1$ to $10 \mathrm{mg} / \mathrm{kg}$ concentrations, comparing to unsupplemented controls. Results showed that 0.1 and $1 \mathrm{mg} / \mathrm{kg}$ concentrations had no effects on black soldier fly larval survival, pupation, or eclosion. However, $10 \mathrm{mg} / \mathrm{kg}$ sulphonamide concentrations had a significantly negative impact on larval and pupal survival, body weight, pupation, and eclosion. Sulfadiazine was also detected in prepupae originating from larvae with feed supplements of 1 and $10 \mathrm{mg} / \mathrm{kg}$, though at lower than input supplement concentrations $(0.4663$ and $0.7814 \mathrm{mg} / 100$ larvae, respectively). These data indicate that black soldier fly larvae can reduce some sulphonamides, but depending on the concentration, may be detrimental to black soldier fly growth and development, while harbouring residues through the prepupal stage. These data underscore the importance of caution when generalising data across all life stages and antibiotic classes (GAO et al., 2019).

Research on larvae raised on a variety of animal manures with or without antibiotic supplementation, and identifying key pathogens (both naturally occurring and intentionally inoculated), their frequency of occurrence, and expression of ARGs and virulence factors in both the digested manure and black soldier fly larvae are valuable. Such approaches will allow for an assessment of the utility of black soldier fly as a method to reduce antimicrobial agents and related compounds. Data may also allow for industrialisation of such processes that mitigate emergence, spread, or persistence of antibiotic resistant pathogens in the animal waste residue produced. Furthermore, these data would be useful for the federal government when reviewing current regulations on the use of insect protein as feed.

\section{Black soldier fly bioproducts for the future: an example of the potential for other insect species}

The black soldier fly system offers an innovative option for managing animal wastes that can be translated into widespread industrial use, transforming low value waste into high value, upcycled products (Figure 1), while also producing protein for use as livestock feed. Black soldier fly products for animal feeds (as whole insects, protein meals, fats, etc.) are currently the main (and most wellknown) outputs when the black soldier fly is used for waste management. However, we recognise that until the biosafety of products generated from manure management can be ensured through continued research on the topic, in addition to the stigma associated with such a process, products generated from manure management should not enter the food stream and should be as purified as possible. This system would be useful worldwide to support circular economies in rural and urban locations worldwide, and even low-earth-orbit environments.

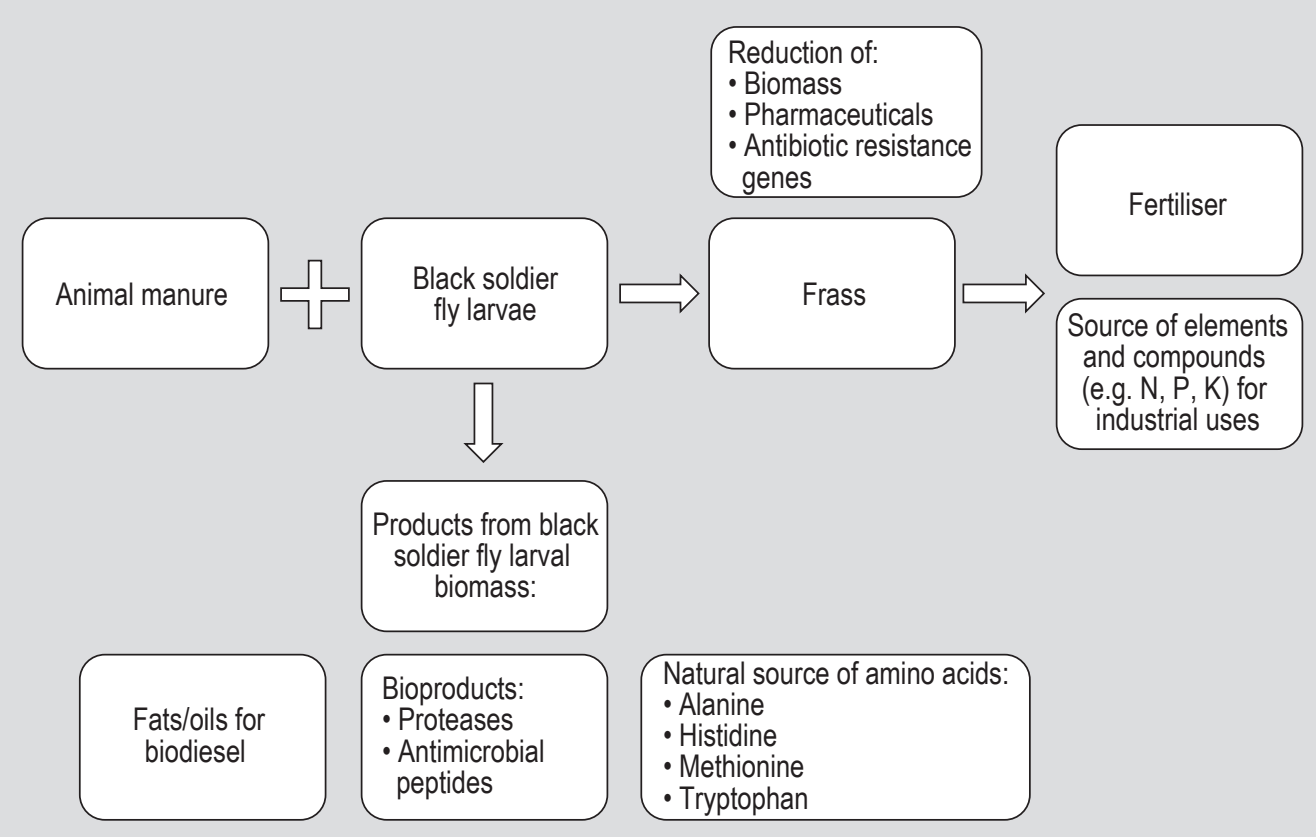

Figure 1. A diagram of the potential products and benefits that could be generated by processing animal manure with black soldier fly larvae. 


\section{Biodiesel}

Black soldier fly larvae are rich in many nutrients, especially fats and fatty acids, making them ideal candidates for renewable sources of biodiesel (Zheng et al., 2012) The high ratio of medium chain saturated to polyunsaturated fatty acids makes larval black soldier fly fats ideal for producing biodiesel (Surendra et al. 2016). Li et al. (2011) were the first to investigate the conversion of dairy manure into biodiesel. At their laboratory scale, approximately $1.25 \mathrm{~kg}$ of manure yielded approximately $16 \mathrm{~g}$ of biodiesel. Although this resulting amount (1.26\%) might seem small, at an industrial scale, this translate to a massive amount of biodiesel. For example, the average dairy cow produces approximately $36 \mathrm{~kg}$ of manure per day per $450 \mathrm{~kg}$ of weight (United States Department of Agriculture, 1995). Consider, an average weight $(680 \mathrm{~kg})$ mature Holstein cow produced approximately $54 \mathrm{~kg}$ of manure per day. If industrialised, such waste could be transformed to $0.68 \mathrm{~kg}$ of biodiesel. A black soldier fly facility co-located with a dairy farm with 2,000 head of cattle could produce $1,360 \mathrm{~kg}$ of biodiesel/ day. At a density of $0.88 \mathrm{~kg} / \mathrm{l}$ (Alleman et al., 2016), this equates to approximately 1,550 l of biodiesel/day. At Huazhong Agricultural University in Wuhan, China, a biogas plant mixes agricultural waste streams (i.e. corncobs and swine manure) to optimise energy yield (Li et al., 2015). A 3:2 ratio of volatile solids was found to yield the most biogas, and the resulting residue investigated for biodiesel production. Bioconversion of this residue by black soldier fly larvae yielded $0.79 \mathrm{~g}$ biodiesel per $100 \mathrm{~g}$ of residue. The authors extrapolated from their study that the amount of corncob and manure needed to produce 1 metric ton of biodiesel could come from 16.78 hectares of corn and 387 head of swine per year. As another example, in June 2019, an estimated 75.5 million pigs were being raised in the USA (Barrett, 2019). If pig wastes were co-digested with corn residue for biogas production, and the biogas residue subsequently digested by black soldier fly larvae, the manure generated from US swine production could yield 195,090 metric tons (or approximately 172 million litres) of biodiesel annually. As of April 2020, China was estimated to produce approximately 2.6 times more pork than the USA, and 1.4 times more than the EU in 2020 (Shahbandeh, 2020). The amount of biodiesel that could result from swine production alone could be massive; the aforementioned volume of 172 million litres could replace approximately $1 \%$ of the total diesel used in the USA in 2019 (United States Energy Information Administration, 2020).

\section{Microbiological products}

Products from the black soldier fly larvae could result in a thriving industry to supply broad needs in waste management, agriculture and home garden protection, pharmaceuticals, and remediation of industrial biofouling. Resulting black soldier fly-derived products, such as antimicrobial peptides, probiotics and prebiotics, represent promising strategies for selective microbial control in manure management. But these products may also offer additional practical benefits to society, such as antimicrobials in treating infections or in reducing biofouling. Some of these alternatives have been reported to embody most or all of the essential antibiotics' functions, while also being less likely to induce bacterial resistance (Alvarez et al., 2019; Elhag et al., 2017; Vogel et al., 2018; Wu et al., 2018). As discussed above, research has showed that a black soldier fly diet and associated bioproducts modify gut microbial communities, modulate immune systems, reduce or inhibit pathogens, and establish a favourable gut microbiome. Thus, the continued identification of novel black soldier fly-associated microbial strains could lead to the production of a microbial cocktail for use as a manure pretreatment for more efficient waste conversion to black soldier fly protein and lipids. And, as microbial amendment to manure reduced black soldier fly development time (Yu et al., 2011), this application would have a direct impact on the productivity of black soldier fly in industrial applications of waste management. Furthermore, antimicrobial peptide testing will determine if any of the isolated AMPs have activity against other pathogens, or with microbial signalling or biofilm development. Indeed, research conducted thus far has yielded encouraging data that compel continuation into the investigation of black soldier fly bioconversion of animal manure, for optimisation aiming to ensure animal, food and environmental safety, while producing products of quality and environmental value.

The antimicrobial properties of insect haemolymph have been known and used for many years in traditional medicine (Seabrooks and $\mathrm{Hu}, 2017$ ). It is not surprising, then, that the AMPs produced in black soldier fly larval haemolymph, excretions, and secretions are attractive options for antimicrobial therapeutics; in fact, they have been shown to have comparable, synergistic, or improved activity over traditional antibiotics against important human pathogens, as described above (Seabrooks and $\mathrm{Hu}$, 2017; Wu et al., 2018). Antimicrobial effects by black soldier fly larval extracts have also been demonstrated toward $E$. coli, Micrococcus luteus, Pseudomonas fluorescens and B. subtilis biofilms (Muller et al., 2017; O’Toole and Kolter, 1998), and also against plant pathogens (Park et al., 2015). These data are encouraging in that black soldier fly AMPs could be suitable as alternative or a combined therapy against a broad array of plant and animal infections, with potential to reduce antimicrobial resistance, with additional application for bioremediation and biofouling control. But, the concentrations of AMPs needed for clinical trials and other large-scale applications may be an obstacle for bringing black soldier fly AMPs to market. Other obstacles, such as potential cytotoxic, immunogenic, and allergenic reactions must also be considered. Nevertheless, continued investigations are merited in that black soldier fly mass 
production may be beneficial to produce desired AMP concentrations, as would be synthesising AMPs and optimising AMP properties.

\section{Fertiliser}

Once digested by black soldier fly larvae, the material remaining (frass) is lower in moisture content, mass, and nutrient content, making it more suitable (both economically and environmentally) for land applications as a fertiliser than the raw manure itself. Black soldier fly larvae are capable of reducing manure mass and nutrients in manure (Matos et al., 2020). In dairy, poultry, and swine manure, black soldier flies reduce dry matter by $26-78 \%$ (Li et al., 2011; Myers et al., 2014; ur Rehman et al., 2017b), 36-60\% (Lalander et al., 2019; Xiao et al., 2018), and 33-56\% (Miranda et al., 2019; Newton et al., 2005), respectively. Furthermore, black soldier fly larvae also reduce numerous nutrients that could otherwise be dangerous to the environment if overapplied as fertiliser. In dairy, poultry, and swine manure, nitrogen is reduced by 6-50\% (Liu et al., 2019; Myers et al., 2014), 14-82\% (Liu et al., 2019; Oonincx et al., 2015a), and 13-37\% (Lalander et al., 2015; Liu et al., 2019), respectively. In dairy manure, phosphorus content is reduced by $61-70 \%$ (Myers et al., 2014), and when reared on swine manure, phosphorus is reduced by $44 \%$, respectively (Newton et al., 2005). Though, Oonincx et al. (2015a) and Liu et al. (2019) found phosphorous increased over time for all three manure types; therefore, variation across studies may be due to differences in methodologies. Metals such as zinc, iron, and copper are also reduced by $26-85 \%$ in dairy, swine, and poultry manure (C.D. Miranda., T.L. Crippen, J.A. Cammack, and J.K. Tomberlin, unpublished data). Unfortunately, few studies exist on the utility of black soldier fly larval frass as a fertiliser, and even fewer studies used animal manure as the starting material. Zhu et al. (2012) found that black soldier fly larval frass produced from swine manure resulted in faster germination of cucumber and Chinese cabbage seeds in comparison to traditionally composted swine manure. Although the data are promising, more research is needed to understand the full potential and limitations of black soldier fly digested animal manure as a fertiliser.

\section{Other direct black soldier fly products}

Bioactive products from the black soldier fly could also be used as a green technology in pest management. As many organisations and individuals are turning more toward integrated pest management and practices, and organic farming, the black soldier fly and its products may be an attractive resource. For instance, black soldier fly larvae produce allomones that are repellent to house flies, resulting in the reduction in house fly occurrence and subsequent oviposition (Bradley and Sheppard, 1984; Sheppard, 1983). Farming the insect for integrated pest management would provide a means to aid in controlling house fly populations. However, the studies showed that the time black soldier fly larvae occupied the manure influenced house fly ovipositional responses (Bradley and Sheppard, 1984), suggesting that a constant black soldier fly population might need to be in place for efficient housefly reduction. Further, geographical ranges of black soldier flies and systematics of adaptation and genetics of the pests need to be considered for targeted or broad use. For these reasons, isolation of the allomones would seem to be a more beneficial approach.

Black soldier fly larvae also produce trypsin and chymotrypsin, digestive enzymes responsible for protein break down through interactions with targeted amino acids (Kim et al., 2011a,b; Park et al., 2012). These proteases are utilised commercially for scientific research to understand protein structure and function, but also in broad food processing to improve the functional and nutritional quality of food proteins, as ingredients in detergents, in the pharmaceutical industry as therapeutic agents, and for use in bioremediation (Shah and Mital, 2018; Yu and Ahmedna, 2012; Zhou et al., 2011). Commercial sources for proteases, such as trypsin and chymotrypsin, include plants, animals, and microbes. But several factors such as the availability of plants and animals for protease retrieval, land for cultivation and growth, climatic conditions, and agricultural policies, could restrict commercial production of these resources. Furthermore, isolation from microbes would also require sophisticated equipment and skills to prevent contamination. Mass production of insects, such as the black soldier fly, that would result in protease isolation is an interesting alternative to the previously mentioned sources, due to the ease of rearing and reduced space and nutritional needs. Additionally, the wide range of substrates used by black soldier fly could be exploited for those diverse protease commercial applications. However, the full scope of proteases and other biologically active enzymes in black soldier fly larvae, their activities, substrate specificity, $\mathrm{pH}$ tolerance, and thermotolerance is lacking. These, along with bioengineering for a robust yield, will need to be solved before these black soldier fly enzymes could be utilised commercially.

\section{Individual components}

In contrast to the old adage, we speculate the sum of the parts is greater than the whole especially as related to the black soldier fly. Black soldier fly larvae are quite nutritionally rich, especially at the amino acid level. Compared to soybean meal, black soldier flies contain higher levels of alanine, methionine, histidine, and tryptophan (Barragan-Fonseca et al., 2017). Black soldier fly larvae are also high in fatty acids (Oonincx et al., 2015b) particularly lauric acid, which has known antiviral and antibacterial properties (Gasco et al., 2018). However, as mentioned above, techniques for the isolation and extraction of these 
compounds must be available and affordable before the full potential of insects and the associated products can be fully appreciated. Further research is needed to identify the processes (both the order/sequence and extraction/ purification techniques) that could be implemented to yield the most benefits from the insect biomass. For example, once the insect biomass is dried, oil can be extracted for use as biodiesel, or further fractionated into specific fatty acids. Additionally, provided that the drying or subsequent extraction techniques do not damage the bioproducts of interest, amino acids, chitin, antimicrobial peptides, and/or enzymes could be subsequently extracted from the defatted biomass.

\section{Conclusions}

Using black soldier fly larvae for manure management is a win-win across the board. Their digestion reduces biomass, nutrients, odorous volatile organic compounds, and pathogens, while creating numerous products of value that can have both direct and indirect positive impacts on agriculture. Imagine a society where we could truly come full circle: brewery waste, post-consumer food waste, or food processing by products, are diverted to a black soldier fly farm, where it is upcycled by the larvae into feed for chickens. The resulting poultry manure is diverted to yet another black soldier fly farm, where it is upcycled by the larvae into purified proteins and amino acids for aquaculture feeds, and oil for biodiesel that powers the trucks transporting the materials. The frass from both black soldier fly farms is used as a soil amendment in crop production, and used to grow more corn and soybean, which can now be diverted to produce food for people. The possibilities of such a circular economy are endless. Regardless, black soldier fly data to date demonstrate what can be done with insects that digest manure. The question remains: will the lesser mealworm, house fly, and other insects be optimised and embraced for such abilities?

\section{Conflict of interest}

The authors declare no conflict of interest.

\section{References}

Adhikari, M., Paudel, K.P., Martin Jr, N.R. and Gauthier, W.M., 2005. Economics of dairy waste use as fertilizer in central Texas. Waste Management 25: 1067-1074. https://doi.org/10.1016/j. wasman.2005.06.012

Alleman, T.L., McCormick, R.L., Christensen, E.D., Fioroni, G. and Moriarty, K., 2016. Biodiesel handling and use guide. US Department of Energy, Washington, DC, USA.
Alvarez, D., Wilkinson, K.A., Treilhou, M., Tene, N., Castillo, D. and Sauvain, M., 2019. Prospecting peptides isolated from black soldier fly (Diptera: Stratiomyidae) with antimicrobial activity against Helicobacter pylori (Campylobacterales: Helicobacteraceae). Journal of Insect Science 19(6): 17. https://doi.org/10.1093/jisesa/iez120

Alyokhin, A., Buzza, A. and Beaulieu, J., 2019. Effects of food substrates and moxidectin on development of black soldier fly, Hermetia illucens. Journal of Applied Entomology 143: 137-143.

Augére-Granier, M.-L. 2019. The EU poultry meat and egg sector: main features, challenges and prospects. European Parliamentary Research Service, Brussels, Belgium.

Axtell, R.C. and Arends, J.J., 1990. Ecology and management of arthropod pests of poultry. Annual Review of Entomology 35: 101-126.

Axtell, R.C. and Edwards, T.D., 1970. Hermetia illucens control in poultry manure by larviciding. Journal of Economic Entomology 63: 1786-1787.

Axtell, R.C., 1986. Fly management in poultry production: cultural, biological, and chemical. Poultry Science 65: 657-667.

Azzollini, D., Wibisaphira, T., Lakemond, C.M.M. and Fogliano, V., 2019. Toward the design of insect-based meat analogue: the role of calcium and temperature in coagulation behavior of Alphitobius diaperinus proteins. LWT 100: 75-82.

Barragan-Fonseca, K.B., Dicke, M. and Van Loon, J.J.A., 2017. Nutritional value of the black soldier fly (Hermetia illucens L.) and its suitability as animal feed - a review. Journal of Insects as Food and Feed 3: 105-120. https://doi.org/10.3920/JIFF2016.0055

Barrett, J., 2019. United States hog inventory up 4 percent. United States Department of Agriculture, National Agricultural Statistics Service, Washington, DC, USA.

Barth, C.L., 1986. Fly control through manure management. Poultry Science 65: 668-674.

Beard, R.L. and Sands, D.C., 1973. Factors affecting degradation of poultry manure by flies. Environmental Entomology 2: 801-806.

Bertone, M.A., Green, J.T., Washburn, S.P., Poore, M.H. and Watson, D.W., 2006. The contribution of tunneling dung beetles to pasture soil nutrition. Forage and Grazinglands 4: 1-12.

Beskin, K.V., Holcomb, C.D., Cammack, J.A., Crippen, T.L., Knap, A.H., Sweet, S.T. and Tomberlin, J.K., 2018. Larval digestion of different manure types by the black soldier fly (Diptera: Stratiomyidae) impacts associated volatile emissions. Waste Management 74: 213-220. https://doi.org/10.1016/j.wasman.2018.01.019

Borrelli, L., Coretti, L., Dipineto, L., Bovera, F., Menna, F., Chiariotti, L., Nizza, A., Lembo, F. and Fioretti, A., 2017. Insect-based diet, a promising nutritional source, modulates gut microbiota composition and SCFAs production in laying hens. Scientific Reports 7: 16269. https://doi.org/10.1038/s41598-017-16560-6

Bradley, S.W. and Sheppard, D.C., 1984. House fly oviposition inhibition by larvae of Hermetia illucens, the black soldier fly. Journal of Chemical Ecology 10: 853-859.

Cai, M., Ma, S., Hu, R., Tomberlin, J.K., Thomashow, L.S., Zheng, L., Li, W., Yu, Z. and Zhang, J., 2018a. Rapidly mitigating antibiotic resistant risks in chicken manure by Hermetia illucens bioconversion with intestinal microflora. Environmental Microbiology 20: 40514062. https://doi.org/10.1111/1462-2920.14450 
Cai, M., Ma, S., Hu, R., Tomberlin, J.K., Yu, C., Huang, Y., Zhan, S., Li, W., Zheng, L., Yu, Z. and Zhang, J., 2018b. Systematic characterization and proposed pathway of tetracycline degradation in solid waste treatment by Hermetia illucens with intestinal microbiota. Environmental Pollution 242: 634-642. https://doi. org/10.1016/j.envpol.2018.06.105

Cammack, J.A. and Tomberlin, J.K., 2017. The impact of diet protein and carbohydrate on select life-history traits of the black soldier fly Hermetia illucens (L.) (Diptera: Stratiomyidae). Insects 8: 56. https://doi.org/10.3390/insects8020056

Carbajal, C., Picazo, A., Gutierrez, S., Blackmon, S., Perez, G., Gonzlez, A., Fuentes, E., Wickham, C., Lopez, C., Johnson, D., and Kannan, S. 2017. Genesis of antibiotic resistance XXVII: action plan for Global Union for Antibiotics Research and Development (GUARD) to mitigate AR pandemic (ARP). FASEB Journal 31: 777.

Centers for Disease Control and Prevention (CDC), 2015. National action plan for combating antibiotic-resistant bacteria (national action plan). CDC, Atlanta, GA, USA.

Chang, C.C.Y. and Janzen, H.H., 1996. Long-term fate of nitrogen from annual feedlot manure applications. Journal of Environmental Quality 25: 785-790.

Chee-Sanford, J.C., Mackie, R.I., Koike, S., Krapac, I.G., Lin, Y.F., Yannarell, A.C., Maxwell, S. and Aminov, R.I., 2009. Fate and transport of antibiotic residues and antibiotic resistance genes following land application of manure waste. Journal of Environmental Quality 38(3): 1086-1108.

Chen, S., Liao, W., Liu, C., Elliott, D.C., Brown, M.D. and Solana, A.E., 2003. Value-added chemicals from animal manure. US Department of Energy, Oak Ridge, TX, USA. Available at: https://www.osti.gov/ biblio/15009485

Čičková, H., Newton, G.L., Lacy, R.C. and Kozanek, M., 2015. The use of fly larvae for organic waste treatment. Waste Management 35: 68-80. https://doi.org/10.1016/j.wasman.2014.09.026

Čičková, H., Pastor, B., Kozanek, M., Martinez-Sanchez, A., Rojo, S. and Takac, P., 2012. Biodegradation of pig manure by the housefly, Musca domestica: a viable ecological strategy for pig manure management. PLoS ONE 7: e32798. https://doi.org/10.1371/journal.pone.0032798

Cosse, A.A. and Baker, T.C., 1996. House flies and pig manure volatiles: wind tunnel behavioral studies and electrophysiological evaluations. Journal of Agricultural Entomology 13: 301-317.

Crippen, T.L., Sheffield, C.L., Esquivel, S.V., Droleskey, R.E. and Esquivel, J.F., 2009. The acquisition and internalization of Salmonella by the lesser mealworm, Alphitobius diaperinus (Coleoptera: Tenebrionidae). Vector Borne Zoonotic Diseases 9: 65-72. https:// doi.org/10.1089/vbz.2008.0103

Crippen, T.L., Zheng, L., Sheffield, C.L., Tomberlin, J.K., Beier, R.C. and Yu, Z., 2012. Transient gut retention and persistence of Salmonella through metamorphosis in the lesser mealworm, Alphitobius diaperinus (Coleoptera: Tenebrionidae). Journal of Applied Microbiology 112: 920-926. https://doi.org/10.1111/j.13652672.2012.05265.x

Davis, C.G., Harvey, D., Zahniser, S., Gale, F. and Liefert, W., 2013. Assessing the growth of US broiler and poultry meat exports. A report from the Economic Research Service. USDA, Washington, DC, USA, pp. 1-28.
Diener, S., Zurbruegg, C. and Tockner, K., 2009. Conversion of organic material by black soldier fly larvae: establishing optimal feeding rates. Waste Management \& Research 27: 603-610. https://doi. org/10.1177/0734242x09103838

Edmonds, L., Gollehon, N., Kellogg, R.L., Knight, L., Lander, C., Lemunyon, J., Meyer, D., Moffitt, D.C. and Schaefer, J., 2003. Costs associated with development and implementation of comprehensive nutrient management plans, part I - nutrient management, land treatment, manure and wastewater handling and storage, and recordkeeping. United States Department of Resources Natural Resources Conservation Service, Washington, DC, USA.

Eleftherianos, I., Atri, J., Accetta, J. and Castillo, J.C., 2013. Endosymbiotic bacteria in insects: guardians of the immune system? Frontiers in Physiology 4: 46. https://doi.org/10.3389/ fphys.2013.00046

Elhag, O., Zhou, D., Song, Q., Soomro, A.A., Cai, M., Zheng, L., Yu, Z. and Zhang, J., 2017. Screening, expression, purification and functional characterization of novel antimicrobial peptide genes from Hermetia illucens (L.). PLoS ONE 12: e0169582. https://doi. org/10.1371/journal.pone.0169582

Erickson, M.C., Islam, M., Sheppard, C., Liao, J. and Doyle, M.P., 2004. Reduction of Escherichia coli O157:H7 and Salmonella enterica serovar Enteritidis in chicken manure by larvae of the black soldier fly. Journal of Food Protection 67: 685-690. https:// doi.org/10.4315/0362-028x-67.4.685

European Union (EU), 2016. Action on antimicrobial resistance. EU, Brussels, Belgium. Available at: https://ec.europa.eu/health/ antimicrobial-resistance/eu-action-on-antimicrobial-resistance_en

Food and Agriculture Organisation (FAO), 2006. Livestock's long shadow: environmental issues and options. FAO, Rome, Italy.

Food and Agriculture Organisation (FAO), 2008. Poultry in the $21^{\text {st }}$ century: avian influenza and beyond. In: Thieme, O. and Pilling, D. (eds.) Proceedings of the International Poultry Conference. November 5-7, 2007. FAO, Bangkok, Thailand.

Gao, Q., Deng, W., Gao, Z., Li, M., Liu, W., Wang, X. and Zhu., F., 2019. Effect of sulfonamide pollution on the growth of manure management candidate Hermetia illucens. PLOS ONE. 14: e0216086. https://doi.org/10.1371/journal.pone.0216086

Garcia, R., Baelum, J., Fredslund, L., Santorum, P. and Jacobsen, C.S., 2010. Influence of temperature and predation on survival of Salmonella enterica serovar Typhimurium and expression of invA in soil and manure-amended soil. Applied and Environmental Microbiology 76: 5025-5031. https://doi.org/10.1128/AEM.00628-10

Gasco, L., Finke, M. and Van Huis, A., 2018. Can diets containing insects promote animal health? Journal of Insects as Food and Feed 4: 1-4. https://doi.org/10.3920/JIFF2018.x001

Gold, M., Cassar, C.M., Zurbrügg, C., Kreuzer, M., Boulos, S., Diener, S. and Mathys, A., 2020. Biowaste treatment with black soldier fly larvae: increasing performance through the formulation of biowastes based on protein and carbohydrates. Waste Management 102: 319-329.

Grossman, E., 2014. As dairy farms grow bigger, new concerns about pollution. Yale Environment 360. Available at: https://e360.yale. edu/features/as_dairy_farms_grow_bigger_new_concerns_about_ pollution 
Hall, R.D. and Foehse, M.C., 1980. Laboratory and field tests of CGA72662 for control of the house fly and face fly in poultry, bovine, or swine manure. Journal of Economic Entomology 73: 564-569.

Haruta, S. and Kanno, N., 2015. Survivability of microbes in natural environments and their ecological impacts. Microbes and Environments 30: 123-125. https://doi.org/10.1264/jsme2.ME3002rh Hussein, M., Pillai, V.V., Goddard, J.M., Park, H.G., Kothapalli, K.S., Ross, D.A., Ketterings, Q.M., Brenna, J.T., Milstein, M.B. and Marquis, H., 2017. Sustainable production of housefly (Musca domestica) larvae as a protein-rich feed ingredient by utilizing cattle manure. PLoS ONE 12: e0171708.

Jiang, X., Islam, M., Morgan, J. and Doyle, M.P., 2004. Fate of Listeria monocytogenes in bovine manure-amended soil. Journal of Food Protection 67: 1676-1681. https://doi.org/10.4315/0362028x-67.8.1676

Kaltenpoth, M., 2009. Actinobacteria as mutualists: general healthcare for insects? Trends in Microbiology 17: 529-535. https://doi. org/10.1016/j.tim.2009.09.006

Kaltenpoth, M., Gottler, W., Herzner, G. and Strohm, E., 2005. Symbiotic bacteria protect wasp larvae from fungal infestation. Current Biology 15: 475-479. https://doi.org/10.1016/j.cub.2004.12.084

Keiding, J., 1986. The house-fly: biology and control. World Health Organization, Geneva, Switzerland.

Khan, H.A.A., Shad, S.A. and Akram, W., 2012. Effect of livestock manures on the fitness of house fly, Musca domestica L. (Diptera: Muscidae). Parasitology Research 111: 1165-1171. https://doi. org/10.1007/s00436-012-2947-1

Kim, W., Bae, S., Kim, A., Park, K., Lee, S., Choi, Y., Han, S., Park, Y. and Koh, Y., 2011a. Characterization of the molecular features and expression patterns of two serine proteases in Hermetia illucens (Diptera: Stratiomyidae) larvae. BMB Reports 44: 387-392.

Kim, W., Bae, S., Park, K., Lee, S., Choi, Y., Han, S. and Koh, Y., 2011 b. Biochemical characterization of digestive enzymes in the black soldier fly, Hermetia illucens (Diptera: Stratiomyidae). Journal of Asia-Pacific Entomology 14: 11-14. https://doi.org/10.1016/j. aspen.2010.11.003

Kim, Y.B., Kim, D., Jeong, S., Lee, J.K., T., Lee, H. and Lee, K., 2020. Black soldier fly larvae oil as an alternative fat source in broiler nutrition. Poultry Science 99: 3133-3143.

Kudva, I.T., Blanch, K. and Hovde, C.J., 1998. Analysis of Escherichia coli $\mathrm{O} 157: \mathrm{H} 7$ survival in ovine or bovine manure and manure slurry. Applied and Environmental Microbiology 64: 3166-3174. https:// doi.org/10.1128/AEM.64.9.3166-3174.1998

Kyakuwaire, M., Olupot, G., Amoding, A., Nkedi-kizza, P. and Ateenyi, B.T., 2019. How safe is chicken litter for land application as an organic fertilizer? A review. International Journal of Environmental Research and Public Health 16: 3521.

Lalander, C., Diener, S., Zurbrügg, C. and Vinnerås, B., 2019. Effects of feedstock on larval development and process efficiency in waste treatment with black soldier fly (Hermetia illucens). Journal of Cleaner Production 208: 211-219.

Lalander, C., Senecal, J., Gros Calvo, M., Ahrens, L., Josefsson, S., Wiberg, K. and Vinneras, B., 2016. Fate of pharmaceuticals and pesticides in fly larvae composting. Science of the Total Environment 565: 279-286. https://doi.org/10.1016/j.scitotenv.2016.04.147
Lalander, C.H., Fidjeland, J., Diener, S., Eriksson, S. and Vinnerås, B., 2015. High waste-to-biomass conversion and efficient Salmonella spp. reduction using black soldier fly for waste recycling. Agronomy for Sustainable Development 35: 261-271. https://doi.org/10.1007/ s13593-014-0235-4

Larrain, P.S. and Salas, C.F., 2008. House fly (Musca domestica L.) (Diptera: Muscidae) development in different types of manure. Chilean Journal of Agricultural Research 68: 192-197.

Leni, G., Soetemans, L., Jacobs, J., Depraetere, S., Ganotten, N., Bastiaens, L., Calgiani, A. and Sforza, S., 2020. Protein hydrolysates from Alphitobius diaperinus and Hermetia illucens larvae treated with commercial proteases. Journal of Insects as Food and Feed 6: 393-404. https://doi.org/10.3920/JIFF2019.0037

Li, Q., Zheng, L., Qiu, N., Cai, H., Tomberlin, J.K. and Yu, Z., 2011. Bioconversion of dairy manure by black soldier fly (Diptera: Stratiomyidae) for biodiesel and sugar production. Waste Management 31: 1316-1320.

Li, W., Zheng, L., Wang, Y., Zhang, J., Yu, X. and Zhang, Y., 2015. Potential biodiesel and biogas production from corncob by anaerobic fermentation and black soldier fly. Biosource Technology 194: 276-282.

Liu, Q., Tomberlin, J.K., Brady, J.A., Sanford, M.R. and Yu, Z., 2008. Black soldier fly (Diptera: Stratiomyidae) larvae reduce Escherichia coli in dairy manure. Environmental Entomology 37: 1525-1530. https://doi.org/10.1603/0046-225x-37.6.1525

Liu, T., Awasthi, M.K., Chen, H., Duan, Y., Awasthi, S.K. and Zhang, Z., 2019. Performance of black soldier fly larvae (Diptera: Stratiomyidae) for manure composting and production of cleaner compost. Journal of Environmental Management 251: 109593.

Lyons, B.N., Crippen, T.L., Zheng, L., Teel, P.D., Swiger, S.L. and Tomberlin, J.K., 2017. Susceptibility of Alphitobius diaperinus in Texas to permethrin- and beta-cyfluthrin-treated surfaces. Pest Management Science 73: 562-567. https://doi.org/10.1002/ps.4327 MacDonald, J.M., O’Donoghue, E., McBride, W.D., Nehring, R., Sandretto, C. and Mosheim, R., 2007. Profits, costs, and the changing structure of dairy farming. USDA-ERS, Washington, DC, USA.

Manyi-Loh, C.E., Mamphweli, S.N., Meyer, E.L., Makaka, G., Simon, M. and Okoh, A.I., 2016. An overview of the control of bacterial pathogens in cattle manure. International Journal of Environmental Research and Public Health 13(9): 843. https://doi.org/10.3390/ ijerph13090843

Matos, J.S., Barberino, A.T.M.S., De Araujo, L.P., Lôbo, I.P. and De Almeida Neto, J.A., 2020. Potentials and limitations of the bioconversion of animal manure using fly larvae. Waste and Biomass Valorization: 1-24.

Mazza, L., Xiao, X., Ur Rehman, K., Cai, M., Zhang, D., Fasulo, S., Tomberlin, J.K., Zheng, L., Soomro, A.A., Yu, Z. and Zhang, J., 2020. Management of chicken manure using black soldier fly (Diptera: Stratiomyidae) larvae assisted by companion bacteria. Waste Management 102: 312-318. https://doi.org/10.1016/j. wasman.2019.10.055

Miller, A., 1954. Dung beetles (Coleoptera, Scarabaeidae) and other insects in relation to human feces in a hookworm area of southern Georgia. American Journal of Tropical Medicine and Hygiene 3: 372-389. https://doi.org/10.4269/ajtmh.1954.3.372 
Miller, B., Teotia, J. and Thatcher, T., 1974. Digestion of poultry manure by Musca domestica. Journal of British Poultry Science 15: 231-234.

Miranda, C., Cammack, J. and Tomberlin, J., 2020a. Life-history traits of house fly, Musca domestica L. (Diptera: Muscidae), reared on three manure types. Journal of Insects as Food and Feed 6: 81-90. https://doi.org/10.3920/JIFF2019.0001

Miranda, C.D., Cammack, J.A. and Tomberlin, J.K., 2019. Life-history traits of the black soldier fly, Hermetia illucens (L.) (Diptera: Stratiomyidae), reared on three manure types. Animals 9: 281.

Miranda, C.D., Cammack, J.A. and Tomberlin, J.K., 2020b. Mass production of the black soldier fly, Hermetia illucens (L.), (Diptera: Stratiomyidae) reared on three manure types. Animals 20: 1243.

Mohr, C.O., 1943. Cattle droppings as ecological units. Ecological Monographs 13: 275-298.

Morrison, P.E. and Davies, D.M., 1964. Feeding of dry chemically defined diets + egg production in adult house-fly. Nature 201: 104-105. https://doi.org/10.1038/201104a0

Muller, A., Wolf, D. and Gutzeit, H., 2017. The black soldier fly, Hermetia illucens-a promising source for sustainable production of proteins, lipids, and bioactive substances. Zeitschrif fur Naturforschung C 72: 351-363.

Myers, H.M., Tomberlin, J.K., Lambert, B.D. and Kattes, D., 2014. Development of black soldier fly (Diptera: Stratiomyidae) larvae fed dairy manure. Environmental Entomology 37: 11-15. https:// doi.org/10.1093/ee/37.1.11

National Chicken Council, 2019a. Broiler chicken industry key facts 2019. NCC, Washington, DC, USA. Available at: https://www. nationalchickencouncil.org/about-the-industry/statistics/broilerchicken-industry-key-facts/

National Chicken Council, 2019b. U.S. broiler production. NCC, Washington, DC, USA. Available at: https://www. nationalchickencouncil.org/about-the-industry/statistics/u-sbroiler-production/

Newton, L., Sheppard, C., Watson, D., Burtle, G. and Dove, R., 2005. Using the black soldier fly, Hermetia illucens, as a value-added tool for the management of swine manure. North Carolina State University, Raleigh, NC, USA.

Nguyen, T.T.X., Tomberlin, J.K. and Vanlaerhoven, S., 2013. Influence of resources on Hermetia illucens (Diptera: Stratiomyidae) larval development. Journal of Medical Entomology 50: 898-906. https:// doi.org/10.1603/me12260

Nichols, E., Alarcon, V., Forgie, S., Gomez-Puerta, L.A. and Jones, M.S., 2017. Coprophagous insects and the ecology of infectious diseases of wildlife. ILAR Journal 58: 336-342. https://doi.org/10.1093/ ilar/ilx022

Nichols, E., Spector, S., Louzada, J., Larsen, T., Amezquita, S., Favila, M.E. and The Scarabaeinae Research Network, 2008. Ecological functons and ecosystem services providwed by Scarabaeinae dung beetles. Biological Conservaion 161: 1461-1474.

Olsen, M.E., Goh, J., Phillips, M., Guselle, N. and McAllister, T.A., 1999. Giardia cyst and Cryptosporidum oocyst survival in water, soil, and cattle feces. Journal of Environmental Quality 28: 1991-1996.

Olson, M., 2020. Human and animal pathogens in manure. Department of Microbiology and Infectious Diseases, University of Calgary, Calgary, Canada.
Oonincx, D.G.A.B., Van Huis, A. and Van Loon, J.J.A., 2015a. Nutrient utilisation by black soldier flies fed with chicken, pig, or cow manure. Journal of Insects as Food and Feed 1: 131-139. https:// doi.org/10.3920/JIFF2014.0023

Oonincx, D.G.A.B., Van Broekhoven, S., Van Huis, A. and Van Loon, J.J.A., 2015b. Feed conversion, survival and development, and composition of four insect species on diets composed of food byproducts. PLoS ONE 10: e0144601. https://doi.org/10.1371/journal. pone. 0144601

O'Toole, G.A. and Kolter, R., 1998. Initiation of biofilm formation in Pseudomonas fluorescens WCS365 proceeds via multiple, convergent signalling pathways: a genetic analysis. Molecular Microbiology 28: 449-461. https://doi.org/10.1046/j.1365-2958.1998.00797.x

Paniagua Voirol, L.R., Frago, E., Kaltenpoth, M., Hilker, M. and Fatouros, N.E., 2018. Bacterial symbionts in lepidoptera: their diversity, transmission, and impact on the host. Frontiers in Microbiology 9: 556. https://doi.org/10.3389/fmicb.2018.00556

Park, B., Um, K., Choi, W. and Park, S., 2017. Effect of feeding black soldier fly pupa meal in the diet on egg production, egg quality, blood lipid profiles and faecal bacteria in laying hens. European Poultry Science 81.

Park, K.H., Choi, Y.C., Nam, S.H. and Kim, W., 2012. Recombinant expression and enzyme activity of chumotrypsin-like protease from black soldier fly, Hermetia illucens (Diptera: Stratiomyidae). International Journal of Industrial Entomology 25(2): 181-185.

Park, K.H., Kwak, K.W., Nam, S.H., Choi, J.Y., Lee, S.H., Kim, H.G. and Kim, S.H., 2015. Antibacterial activity of larval extract from the black soldier fly Hermetia illucens (Diptera: Stratiomyidae) against plant pahtogens. Journal of Entomology and Zoology Studies 3: 176-179.

Prosser, R.S. and Sibley, P.K., 2015. Human health risk assessment of pharmaceuticals and personal care products in plant tissue due to biosolids and manure amendments, and wastewater irrigation. Environment International 75: 223-233.

Roncolini, A., Milanovic, V., Aquilanti, L., Cardinali, F., Garofalo, C., Sabbatini, R., Clementi, F., Belleggia, L., Pasquini, M., Mozzon, M., Foligni, R., Federica Trombetta, M., Haouet, M.N., Serena Altissimi, M., Di Bella, S., Piersanti, A., Griffoni, F., Reale, A., Niro, S. and Osimani, A., 2020. Lesser mealworm (Alphitobius diaperinus) powder as a novel baking ingredient for manufacturing high-protein, mineral-dense snacks. Food Research International 131: 109031. https://doi.org/10.1016/j.foodres.2020.109031

Rumbos, C.I., Karapanagiotidis, I.T., Mente, E. and Athanassiou, C.G., 2019. The lesser mealworm Alphitobius diaperinus; a noxious pest or a promising nutrient source? Reviews in Aquaculture 11: 1418-1437. Sarpong, D., Oduru-Kwarteng, S., Gyasi, S.F., Buamah, R., Donkor, E., Awuah, E. and Baah, M.K., 2019. Biodegradation by composting of municipal organic solid waste into organic fertilizer using the black soldier fly (Hermetia illucens) (Diptera: Stratiomyidae) larvae. Internationa Journal of Recycling of Organic Waste in Agriculture 8: 45-54.

Sasaki, T., Kobayashi, M. and Agui, N., 2000. Epidemiological potential of excretion and regurgitation by Musca domestica (Diptera: Muscidae) in the dissemination of Escherichia coli O157: H7 to food. Journal of Medical Entomology 37: 945-949. https://doi. org/10.1603/0022-2585-37.6.945 
Seabrooks, L. and Hu, L., 2017. Insects: an underrepresented resource for the discovery of biologically active natural products. Acta Pharmaceutica Sinica B 7: 409-426. https://doi.org/10.1016/j. apsb.2017.05.001

Shah, D. and Mital, K., 2018. The role of trypsin:chymotrypsin in tissue repair. Advances in Therapy 35: 31-42. https://doi.org/10.1007/ s12325-017-0648-y

Shahbandeh, M., 2020. Global pork production, by country. Statista, New York, NY, USA. Available at: https://www.statista.com/ statistics/273232/net-pork-production-worldwide-by-country

Sheng, L., Shen, X., Benedict, C., Su, Y., Tsai, H.C., Schacht, E., Kruger, C.E., Drennan, M. and Zhu, M.J., 2019. Microbial safety of dairy manure fertilizer application in raspberry production. Frontiers in Microbiology 10: 2276. https://doi.org/10.3389/fmicb.2019.02276

Sheppard, C., 1983. House fly and lesser fly control utilizing the black soldier fly in manure management systems for caged laying hens. Environmental Entomology 12: 1439-1442.

Sheppard, D.C., Newton, G.L. and Savage, S., 1994. A value added manure management system using the black soldier fly. Bioresource Technology 50: 275-279.

Sierra, J.M., Fuste, E., Rabanal, F., Vinuesa, T. and Vinas, M., 2017. An overview of antimicrobial peptides and the latest advances in their development. Expert Opinion on Biological Therapy 17: 663-676. https://doi.org/10.1080/14712598.2017.1315402

Sim, W.J., Lee, J.W., Lee, E.S., Shin, S.K., Hwang, S.R. and Oh, J.E., 2011. Occurrence and distribution of pharmaceuticals in wastewater from households, livestock farms, hospitals and pharmaceutical manufactures. Chemosphere 82(2): 179-186.

Sobsey, M.D., Khatib, L.A., Hill, V.R., Alocilja, E. and Pillai, S., 2006. Pathogens in animal wastes and the impacts of waste management practices on their survival, transport and fate. In: Rice, J.M., Caldwell, D.F. and Humenik, F.J. (eds.) Animal agriculture and the environment: national center for manure and animal waste management white papers. ASABE, St. Joseph, MI, USA.

Stanford, K., Reuter, T., Gilroyed, B.H. and McAllister, T.A., 2015. Impacts of sporulation temperature, exposure to compost matrix and temperature on survival of Bacillus cereus spores during livestock mortality composting. Journal of Applied Microbiology 118: 989-997. https://doi.org/10.1111/jam.12749

St-Hilaire, S., Cranfill, K., McGuire, M.A., Mosley, E.E., Tomberlin, J.K., Newton, G.L., Sealey, W., Sheppard, C. and Irving, S., 2007. Fish offal recycling by the black soldier fly produces a foodstuff high in omega-3 fatty acids. Journal of the World Aquaculture Society 38: 309-313.

Sun, Y. and O'Riordan, M.X., 2013. Regulation of bacterial pathogenesis by intestinal short-chain fatty acids. Advances in Applied Microbiology 85: 93-118. https://doi.org/10.1016/B9780-12-407672-3.00003-4

Surendra, K.C., Olivier, R., Tomberlin, J.K., Jha, R. and Khanal, S.K., 2016. Bioconversion of organic wastes into biodiesel and animal feed via insect farming. Renewable Energy 98: 197-202. https://doi. org/10.1016/j.renene.2016.03.022.

Teotia, J.S. and Miller, B.F., 1974. Nutritive content of house fly pupae and manure residue. British Poultry Science 15: 177-182. https:// doi.org/10.1080/00071667408416093
Tomberlin, J.K. and Van Huis, A., 2020. Black soldier fly from pest to 'crown jewel' of the insects as feed industry: an historical perspective. Journal of Insects as Food and Feed 6: 1-4. https://doi.org/10.3920/ JIFF2020.0003

Tomberlin, J.K., Richman, D. and Myers, H.M., 2008. Susceptibility of Alphitobius diaperinus (Coleoptera: Tenebrionidae) from broiler facilities in Texas to four insecticides. Journal of Economic Entomology 101: 480-483.

Tomberlin, J.K., Sheppard, D.C. and Joyce, J.A., 2002. Selected lifehistory traits of black soldier flies (Diptera: Stratiomyidae) reared on three artificial diets. Annals of the Entomological Society of America 95: 379-386. https://doi.org/10.1603/0013-8746(2002)095[0379:sl htob]2.0.co;2

United States Department of Agriculture, 2015. Overview of the United States hog industry: breeding herd efficiency continues to increase. USDA, Washington, DC, USA.

United States Department of Agriculture, 1995. Animal manure management. USDA, Washington, DC, USA. Available at: https://www.nrcs.usda.gov/wps/portal/nrcs/detail/ null/?cid=nrcs143_014211.

United States Energy Information Administration, 2020. Diesel fuel explained. US Energy Information Administration, Washington, DC, USA. Available at: https://www.eia.gov/energyexplained/dieselfuel/use-of-diesel.php

ur Rehman, K., Cai, M., Xiao, X., Zheng, L., Wang, H., Soomro, A.A., Zhou, Y., Li, W., Yu, Z. and Zhang, J., 2017a. Cellulose decomposition and larval biomass production from the co-digestion of dairy manure and chicken manure by mini-livestock (Hermetia illucens L.). Journal of Environmental Management 196: 458-465.

ur Rehman, K., Rehman, A., Cai, M., Zheng, L., Xiao, X., Somroo, A.A., Wang, H., Li, W., Yu, Z. and Zhang, J., 2017b. Conversion of mixtures of dairy manure and soybean curd residue by black soldier fly larvae (Hermetia illucens L.). Journal of Cleaner Production 154: 366-373.

Usui, M., Kawakura, M., Yoshizawa, N., San, L.L., Nakajima, C., Suzuki, Y. and Tamura, Y., 2017. Survival and prevalence of Clostridium difficile in manure compost derived from pigs. Anaerobe 43: 15-20. https://doi.org/10.1016/j.anaerobe.2016.11.004

Vogel, H., Muller, A., Heckel, D.G., Gutzeit, H. and Vilcinskas, A., 2018. Nutritional immunology: diversification and diet-dependent expression of antimicrobial peptides in the black soldier fly Hermetia illucens. Developmental and Comparative Immunology 78: 141-148. https://doi.org/10.1016/j.dci.2017.09.008

Wallace, J.S., Garner, E., Pruden, A. and Aga, D.S., 2018. Occurrence and transformation of veterinary antibiotics and antibiotic resistance genes in dairy manure treated by advanced anaerobic digestion and conventional treatment methods. Environmental Pollution 236: 764-772

Wang, H., Li, H., Gilbert, J.A., Li, H., Wu, L., Liu, M., Wang, L., Zhou, Q., Yuan, J. and Zhang, Z., 2015. Housefly larva vermicomposting efficiently attenuates antibiotic resistance genes in swine manure, with concomitant bacterial population changes. Applied and Environmental Microbiology 81: 7668-7679. 
Wang, H., Sangwan, N., Li, H.-Y., Su, J.-Q., Oyang, W.-Y., Zhang, Z.-J., Gilbert, J.A., Zhu, Y.-G., Ping, F. and Zhang, H.-L., 2017. The antibiotic resistome of swine manure is significantly altered by association with the Musca domestica larvae gut microbiome. The ISME Journal 11: 100-111.

Wang, H., Zhang, Z., Czapar, G.F., Winkler, M.K. and Zheng, J., 2013. A full-scale house fly (Diptera: Muscidae) larvae bioconversion system for value-added swine manure reduction. Waste Management \& Research 31: 223-231.

Wasala, L., Talley, J.L., Desilva, U., Fletcher, J. and Wayadande, A., 2013. Transfer of Escherichia coli O157:H7 to spinach by house flies, Musca domestica (Diptera: Muscidae). Phytopathology 103: 373-380. https://doi.org/10.1094/PHYTO-09-12-0217-FI

Welch, C. and O'Hagan, M., 2010. Officials seek cause of Snohomish dairy-manure spill. The Seattle Times, April 14. Available at: https://www.seattletimes.com/seattle-news/officials-seek-causeof-snohomish-dairy-manure-spill/

World Health Organization, 2015. Global action plan on antimicrobial resistance. WHO, Geneva, Switzerland.

Wu, Q., Patocka, J. and Kuca, K., 2018. Insect antimicrobial peptides, a mini review. Toxins 10: 461. https://doi.org/10.3390/toxins10110461

Xiao, X., Mazza, L., Yu, Y., Cai, M., Zheng, L., Tomberlin, J.K., Yu, J., Van Huis, A., Yu, Z. and Fasulo, S., 2018. Efficient co-conversion process of chicken manure into protein feed and organic fertilizer by Hermetia illucens L.(Diptera: Stratiomyidae) larvae and functional bacteria. Journal of Environmental Management 217: 668-676.

Yu, G., Cheng, P., Chen, Y., Li, Y., Yang, Z., Chen, Y. and Tomberlin, J.K., 2011. Inoculating poultry manure with companion bacteria influences growth and development of black soldier fly (Diptera: Stratiomyidae) larvae. Environmental Entomology 40: 30-35. https:// doi.org/10.1603/EN10126

Yu, J. and Ahmedna, M., 2012. Functions/applications of trypsin in food processing and food science research. In: Weaver, K. and Kelley, C. (eds.) Trypsin: structure, biosynthesis and functions. Nova Science Publishers, Hauppauge, NY, USA, pp. 75-96.
Yuan, Q.B., Zhai, Y.F., Mao, B.Y., Schwarz, C. and Hu, N., 2019. Fates of antibiotic resistance genes in a distributed swine wastewater treatment plant. Water Environmental Research 91: 1565-1575.

Zhang, Z., Wang, H., Zhu, J., Suneethi, S. and Zheng, J., 2012. Swine manure vermicomposting via housefly larvae (Musca domestica): the dynamics of biochemical and microbial features. Bioresource Technology 118: 563-571. https://doi.org/10.1016/j. biortech.2012.05.048

Zheng, L., Hou, Y., Li, W., Yang, S., Li, Q. and Yu, Z., 2012. Biodiesel production from rice straw and restaurant waste employing black soldier fly assisted by microbes. Energy 47: 225-229.

Zhou, F., Tomberlin, J.K., Zheng, L., Yu, Z. and Zhang, J., 2013. Developmental and waste reduction plasticity of three black soldier fly strains (Diptera: Stratiomyidae) raised on different livestock manures. Journal of Medical Entomology 50: 1224-1230.

Zhou, L., Budge, S.M., Ghaly, A.E., Brooks, M.S. and Dave, D., 2011. Extraction, purification and characterization of fish chymotrypsin: a review. American Journal of Biochemistry and Biotechnology 7: 104-123.

Zhu, F.X., Wang, W.P., Hong, C.L., Feng, M.G., Xue, Z.Y., Chen, Y., Yao, Y.L. and Yu, M., 2012. Rapid production of maggots as feed supplement and organic fertilizer by the two-stage composting of pig manure. Bioresource Technology 116: 485-491.

Zi-zhe, C., De-po, Y., Sheng-qing, W., Yong, W., Reaney, M.J., Zhi-min, Z., Long-ping, Z., Guo, S., Yi, N. and Dong, Z., 2017. Conversion of poultry manure to biodiesel, a practical method of producing fatty acid methyl esters via housefly (Musca domestica L.) larval lipid. Fuel 210: 463-471.

Zurek, K. and Nayduch, D., 2016. Bacterial associations across house fly life history: evidence for transstadial carriage from managed manure. Journal of Insect Science 16: 2.

Zurek, L., Schal, C. and Watson, D., 2000. Diversity and contribution of the intestinal bacterial community to the development of Musca domestica (Diptera: Muscidae) larvae. Journal of Medical Entomology 37: 924-928. 
